\title{
LOCUS OF CONTROL SEBAGAI PEMODERASI PENGARUH PARTISIPASI PENYUSUNAN ANGGARAN DAN KEJELASAN SASARAN ANGGARAN TERHADAP KINERJA MANAJERIAL
}

\author{
Asbi Amin ${ }^{1)^{*}}$, Anwar ${ }^{2)}$. \\ ${ }^{1 .}$ Prodi Akuntansi, STIEM Bongaya, Makassar \\ email: asbi.amin@stiem-bongaya.ac.id \\ ${ }^{2}$ Prodi Akuntansi, STIEM Bongaya, Makassar \\ email: anwar@stiem-bongaya.ac.id
}

\begin{abstract}
This research aimed to test the understanding of the budgetary participation and budget target clarity have effect to Manajerial Performance. Locus of Control is able to moderate the effect of budget participation and budget target clarity to Manajerial Performance of South Sulawesi Provincial Government. This research took 54 respondents with a sampling technique is Judgement Sampling. Data collection was carried out through a questionnaire. The data analysis technique used in this study is Moderated Regression Analysis (MRA). Based on the results of the analysis it can be seen that the participation in budgeting and the clarity of budget targets has a positive and significant effect on managerial performance, then the Locus of control is not able to moderate the influence of participation in budgeting and the clarity of budget targets on managerial performance.
\end{abstract}

Keywords: Budget Participation, Budget Target Clarity, Locus of Control, Managerial Performance

\begin{abstract}
ABSTRAK
Tujuan penelitian ini adalah untuk mengetahui apakah partisipasi penyusunan anggaran dan kejelasan sasaran anggaran mempunyai pengaruh terhadap kinerja manajerial. Locus Of Control mampu memoderasi pengaruh partisipasi penyusunan anggaran dan kejelasan sasaran anggaran terhadap kinerja Manajerial Pemerintah Provinsi Sulawesi Selatan. Penelitian ini mengambil sebanyak 54 responden dengan teknik pengambilan sampel adalah teknik Judgement Sampling. Pengumpulan data dilakukan melalui kuesioner. Teknis analisis data yang dipakai dalam penelitian ini adalah Moderated Regression Analysis (MRA). Berdasarkan hasil analisis maka dapat diketahui bahwa partisipasi penyusunan anggaran dan kejelasan sasaran anggaran berpengaruh positif dan signifikan terhadap kinerja manajerial, kemudian Locus of control tidak mampu memoderasi pengaruh partisipasi penysunan anggaran dan kejelasan sasaran anggaran terhadap kinerja manajerial.
\end{abstract}

Kata Kunci: Partisipasi Penyusunan Anggaran, Kejelasan Sasaran Anggaran, Locus of Control, Kinerja Manajerial 


\section{PENDAHULUAN}

Keberhasilan Pemerintah dalam meningkatkan kinerjanya salah satunya dipengaruhi dari cara Pemerintah melaksanakan rencana dalam proses penganggaran dengan sebaik mungkin. Proses penganggaran tentu saja tidak terlepas dari kinerja manajerial sebagai salah satu faktor yang dapat meningkatkan keefektifan organisasional. Dengan melakukan pengukuran kinerja maka dapat memastikan apakah pengambilan keputusan telah dilakukan secara tepat dan objektif dalam suatu organisasi (Bastian, 2010).

Fenomena terdapat gap antara persentase target dan realisasi anggaran pada Laporan Realisasi Anggaran Provinsi Sulawesi Selatan, tahun 2015 terjadi defisit realisasi anggaran sebesar 25,20\%, kemudian tahun 2016 mengalami surplus sebesar 29,33\%, namun pada tahun 2017 kembali terjadi defisit sebesar $16,27 \%$ yang menunjukkan surplus/defisit menggambarkan kinerja manajerial Pemerintah Sulawesi Selatan masih belum maksimal.

Diperlukan partisipasi Manajerial dalam penyusunan anggaran sebagai salah faktor yang dapat mengukur keberhasilan kinerja Manajerial. Partisipasi anggaran merupakan proses yang memberikan gambaran bagaimana setiap individu terlibat dalam penyusunan anggaran pemerintah. Secara umum, partisipasi penyusunan anggaran sebagai pendekatan yang digunakan untuk meningkatkan kinerja manajerial yang nantinya akan meningkatkan efektivitas organisasi (Rantelobo, 2018).

Peningkatan tanggungjawab dan kinerja dari manajerial pemerintah terlihat dari partisipasi dalam penyusunan anggaran mulai dari manajerial level bawah sampai manajarial level menengah. Manajerial level bawah akan menyampaikan gagasan mereka berkaitan dengan tujuan anggaran pemerintah yang disesuaikan dengan kebutuhannya pada periode anggaran tersebut. Dengan berpartisipasinya para manajerial mulai dari level menengah sampai manajerial level bawah dalam penentuan anggaran, maka dapat ambil sebuah keputusan yang sesuai antara susunan anggaran dengan tujuan yang ingin dicapai oleh organisasi. (Rantelobo, 2018).

Faktor lain yang dapat memengaruhi kinerja manajerial yaitu kejelasan sasaran anggaran. Kejelasan sasaran anggaran dapat dijadikan sebagai tolak ukur apakah kinerja pemerintah daerah sudah tercapai atau belum. Semua Manajerial OPD bertanggungjawab menetapkan dan menyusun anggaran selama satu periode angggaran harus bisa memahami dan mempertanggungjawbakan sasaran anggaran yang telah ditetapkan dan disusun tersebut dengan jelas dan spesifik.

Locus of control sebagai salah satu hal yang mempengaruhi bagaimana Manajerial pemerintah dapat mengartikan atau mempresepsikan peristiwa yang dihadapinya terkait perkerjaannya yang berkerja untuk kepemtingan publik karena Locus of control merupakan karakteristik kepribadian yang terdapat dalam diri aparatur pemerintah sehingga dapat dijadikan sebagai alat ukur dalam menilai kinerja manajerial.

Peneliti melakukan pengembangan penelitian berdasarkan rujukan penelitian yang telah dilakukan oleh (Ferial, 2016). Peneliti menguji locus of control sebagai pemoderasi pengaruh partisipasi penyusunan anggaran dan kejelasan sasaran anggaran terhadap kinerja manajerial. Sedangkan penelitian sebelumnya menggunakan variabel locus of control sebagai pemoderasi pengaruh partisipasi penyusunan anggaran dan desentralisasi terhadap kinerja manajerial. Perbedaan penelitian ini dengan penelitian (Ferial, 2016) yaitu penelitian ini dilakukan di Organisasi Perangkat Daerah

151 JOURNAL OF APPLIED MANAGERIAL ACCOUNTING

| Vol. 4, No. 1, 2020, 150-156| ISSN: 2548-9917 
(OPD) Provinsi Sulawesi Selatan sedangkan penelitian (Ferial, 2016) dilakukan hanya pada Dinas Pekerjaan Umum Kabupaten Karanganyar.

\section{Landasan Teori}

\subsection{Partisipasi Penyusunan Anggaran Berpengaruh Terhadap Kinerja Manajerial}

Teori keagenan (Agency theory) yang dikemukakan oleh Berle dan Means (1932) bahwa Manajerial Organisasi Perangkat Daerah (OPD) selaku agen yang berperan serta dalam perencanaan dan pelaksanaan anggaran wajib bertanggung jawab dan memangku amanat dari masyarakat. Partisipasi Manajerial dalam penyusunan anggaran ini membuat konsekuensi atas berhasilnya anggaran dilaksanakan sesuai dengan kebutuhan masyarakat.

Hasil penelitian (Wiratno, Ningsih , \& Putri, 2016), (Ridwan \& Putra, 2016) dan (Giusti, Kustono, \& Effendi, 2018) (Giusti, Kustono, \& Effendi, 2018) menunjukkan bahwa partisipasi penganggaran berpengaruh signifikan terhadap kinerja manajerial. Sehingga hipotesis yang akan diuji sebagai berikut :

H1: Partisipasi penyusunan anggaran berpengaruh positif dan signifikan terhadap kinerja manajerial Pemerintah Provinsi Sulawesi Selatan.

\subsection{Pengaruh Kejelasan Sasaran} Anggaran Terhadap Kinerja Manajerial

Teori keagenan (Agency theory) yang dikemukakan oleh Berle dan Means (1932) bahwa selaku agen yang memangku tugastugas dari masyarakat, Manajerial OPD yang ikut serta dalam perencanaan dan pelaksanaan anggaran, harus mampu menyusun anggaran secara jelas dan spesifik. Hasil penelitian Beny (2012), Wahyuni.et.al (2014) dan Denny (2015) menunjukkan bahwa kejelasan sasaran anggaran berpengaruh positif dan signifikan terhadap kinerja manajerial. Sehingga hipotesis yang akan diuji sebagai berikut :

$\mathrm{H} 2$ : Kejelasan sasaran anggaran berpengaruh positif dan signifikan terhadap kinerja manajerial Pemerintah Provinsi Sulawesi Selatan.

\subsection{Partisipasi Penyusunan Anggaran Terhadap Kinerja Manajerial yang dimoderasi oleh locus of control}

Theory of Planned Behavior menyatakan bahwa seseorang dapat berperan berdasarkan intensi atau niatnya hanya jika ia memiliki kontrol terhadap perbuatannya (Ajzen, 2005). Teori ini tidak hanya menekankan pada rasionalitas dari kelakuan manusia, tetapi juga pada keyakinan bahwa target tingkah laku tidak berada di bawah kontrol individu lain. (Ajzen, 2005).

Locus of control tidak mampu memoderasi pengaruh partisipasi anggaran dengan kinerja manajerial telah dilakukan oleh (Haryanto, 2018). Sehingga hipotesis yang akan diuji sebagai berikut :

H3: Locus of control tidak memoderasi pengaruh partisipasi penyusunan anggaran terhadap kinerja Manajerial Pemerintah Provinsi Sulawesi Selatan.

2.4 Pengaruh Kejelasan Sasaran Anggaran Terhadap Kinerja Manajerial yang dimoderasi oleh locus of control

Manajerial pemerintah yang memiliki internal locus of control sebagai karakteristik kepribadiannya akan melihat kejelasan sasaran anggaran yang disusunnya sebagai segala sesuatu yang dapat diramalkan dan akan berakibat pada tingkah lakunya dalam pekerjaannya. Lain halnya dengan Manajerial pemerintah yang memiliki external locus of control sebagai karakteristik kepribadiannya akan mempertimbangkan kejelasan sasarn anggaran tidak dapat diramalkan, sehingga tidak akan memengaruhi tingkah lakunya dalam bekerja.

Penelitian yang telah dilakukan oleh (Threzasyari, 2017) menemukan bahwa locus of control memoderasi kejelasan anggaran terhadap senjangan anggaran. Hipotesis yang akan diuji sebagai berikut : 
H4: Locus of control tidak mampu memoderasi kejelasan sasaran anggaran terhadap kinerja Manajerial Pemerintah Provinsi Sulawesi Selatan.

\section{KERANGKA PENELITIAN}

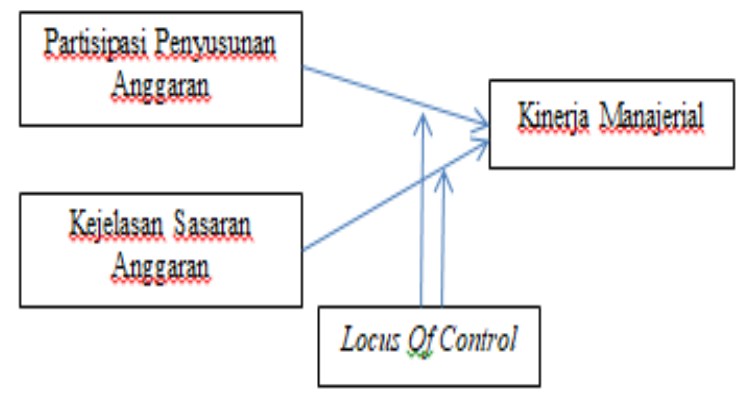

Gambar 1. Kerangka Penelitian

\section{METODE PENELITIAN}

\section{Pendekatan Penelitian}

Metode kuantiatif yang berbentuk asosiatif digunakan dalam penelitian ini sebagai desain penelitian.

\section{Populasi dan Sampel}

Organisasi Perangkat Daerah yang ada di Provinsi Sulawesi Selatan, berjumlah 27 Dinas merupakan populasi dalam peneitian karena dianggap sebagai objek yang berhubungan dengan partisipasi penyusunan anggaran, kejelasan sasaran anggaran, locus of control dan kinerja manajerial.

Adapun teknik pengambilan sampel yang digunakan yaitu Judgement Sampling dengan 2 orang pada setiap Dinas Provinsi Sulawesi Selatan diwakili oleh Kepala Penatausahaan Keuangan dan Pejabat Pembuat Komitmen dengan total sampel 54 orang dengan pertimbangan peneliti mereka berkompeten dalam penyusunan anggaran.

\section{Teknik Pengumpulan Data}

Melalui penyebaran kuesioner kepada sampel penelitian, maka data dapat dikumpulkan kemudiian diolah untuk menguji hubungan antara variabel dependen dengan variabel independen.

\section{Definisi Operasional}

Deskripsi variabel dalam penelitian ini adalah sebagai berikut:

\section{Partisipasi Penyusunan Anggaran}

Partisipasi dalam penyusunan anggaran merupakan ikut sertanya para manajerial OPD dalam menyusun target anggaran yang kemudian dinilai kinerjanya berdasarkan pencapaian target anggaran. Indikator pengukuran partisipasi penyusunan anggaran yaitu : 1)Keterlibatan, 2)Pengaruh jabatan, 3) Kontribusi.

\section{Kejelasan Sasaran Anggaran}

Kejelasan sasaran anggaran merupakan ukuran keberhasilan perencanaan dan pelaksanaan anggaran yang telah disusun secara jelas dan spesifik kemudian dipertanggungjawabkan oleh Manajerial OPD. Indikator pengukuran kejelasan sasaran anggaran yaitu: 1)Jelas, 2)Spesifik, 3) Dapat Dimengerti.

\section{Locis Of Control}

Locus of control merupakan ukuran dimana Manajerial OPD menerima tanggung jawab pekerjaannya dan menerima risiko terhadap apa yang terjadi pada diri mereka. Indikator pengukuran locus of control yaitu: 1) Kemampuan, 2) Minat, 3) Usaha, 4) Nasib, 5) Lingkungan Sosial dan 6) Pengaruh Orang Lain.

\section{Kinerja Manajerial}

Kinerja manajerial merupakan sejauh mana Manajerial melaksanakan fungsi-fungsi manajemen dalam mewujudkan sasaran dan tujuan anggaran. Indikator pengukuran kejelasan sasaran anggaran yaitu : 1)Jelas, 2)Spesifik, 3) Dapat Dimengerti. Penggunaan indikator ini didasarkan fakta empiris pada objek penelitian. Skala data yang digunakan adalah skala data ordinal.

\section{Teknik Analisis}

Metode analisa kuantitatif dengan pendekatan statistik yang digunakan dalam 
penelitian ini dilakukan dengan mengumpulkan, mengolah dan menginterpretasikan data yang diperoleh tentang partisipasi penyusunan anggaran dan kejelasan sasaran anggaran, locus of control dan kinerja manajerial. Sementara itu, model regresi berganda dengan pendekatan uji Moderated Regression Analysis (MRA) dengan bantuan program SPSS for windows digunakan untuk menguji hipotesis pada penelitian ini.

Model yang digunakan pada penelitian ini adalah sebagai berikut :

$$
\begin{gathered}
Y=a+\beta_{1} X_{1}+\beta_{2} X_{2}+\beta_{3} X_{1} X_{3} \\
+\beta_{4} X_{2} X_{3}+e
\end{gathered}
$$

\section{Keterangan :}

$\alpha \quad$ : Konstanta

e : Koefision error

$\beta 1-\beta 3$ : koefisien regresi

$\mathrm{X} 1$ : Partisipasi Penyusunan anggaran

X2 : Kejelasan sasaran anggaran

$\mathrm{X} 3$ : Locus of control

$\mathrm{X}_{1} \mathrm{X}_{3}$ :Interaksi partisipasi penyusunan anggaran dengan locus of control

$\mathrm{X}_{2} \mathrm{X}_{3}$ :Interaksi kejelasan sasaran anggaran dengan locus of control

Y : Kinerja Manajerial (KM)

\section{HASIL DAN PEMBAHASAN Hasil Penelitian}

\begin{tabular}{|c|c|c|c|c|}
\hline Variabel & Koefisien & t-ratio & $\begin{array}{l}\text { Probability } \\
\text { Significancy }\end{array}$ & Keputusan \\
\hline $\begin{array}{l}\text { Partisipasi } \\
\text { Penyusunan Anggaran } \\
\text { (X1) }\end{array}$ & 0,329 & 3,412 & 0,002 & Signifikan \\
\hline $\begin{array}{l}\text { Kejelasan Sasaran } \\
\text { Anggaran (X2) }\end{array}$ & 0,550 & 2,187 & 0,000 & Signifikan \\
\hline $\begin{array}{l}\text { Interaksi partisipasi } \\
\text { penyusunan anggaran } \\
\text { dengan locus of } \\
\text { control (X1*X3) }\end{array}$ & 0,136 & 1,818 & 0,882 & $\begin{array}{l}\text { Tidak } \\
\text { Signifikan }\end{array}$ \\
\hline $\begin{array}{l}\text { Interaksi kejelasan } \\
\text { sasaran anggaran } \\
\text { dengan locus of } \\
\text { control (X2*X3) }\end{array}$ & $-0,532$ & 1,793 & 0,505 & $\begin{array}{l}\text { Tidak } \\
\text { Signifikan }\end{array}$ \\
\hline Konstanta & 0,531 & 4,248 & 0,000 & \\
\hline Adjusted $\mathrm{R}^{2}$ & \multicolumn{4}{|l|}{0,533} \\
\hline $\begin{array}{l}\text { F-ratio } \\
(\text { Prob }- \text { Sig })\end{array}$ & \multicolumn{4}{|l|}{$\begin{array}{l}18,993 \\
0,000\end{array}$} \\
\hline $\mathrm{N}$ & \multicolumn{4}{|l|}{54} \\
\hline
\end{tabular}

Tabel 1. Rekapitulasi Analisis Regresi

Sumber : data diolah dengan SPSS, 2019

Berdasarkan hasil rekapitulasi pada tabel di atas menunjukkan variabel partisipasi penyusunan anggaran dan kejelasan sasaran anggaran signifikan menjelaskan 53,30\% kinerja manajerial OPD Provinsi Sulawesi Selatan terlihat pada nilai adjusted $R$ square yang diperoleh adalah 0,533 atau 53,30\%, sedangkan sisanya sebesar $46,70 \%$ dijelaskan oleh sebab-sebab lain diluar model dalam penelitian ini.

Hasil rekapitulasi pada tabel di atas juga menunjukkan bahwa hasil analisis regresi ANOVA (Analysis of Variant) F-hitung = 18,993 dan F-tabel yaitu 2,790 memperlihatkan F-hitung > F-tabel dengan nilai signifikansi 0,000 lebih kecil dari taraf signifikansi $5 \%$. Maka dapat disimpulkan bahwa partisipasi penyusunan anggaran, kejelasan sasaran anggaran dan locus of control secara simultan berpengaruh terhadap kinerja manajerial pada Pemerintah Provinsi Sulawesi Selatan.

Hasil analisis Moderated Regression Analysis (MRA) ditemukan persamaan sebagai berikut:

$$
\begin{aligned}
K M=0,531 & +0,329 X_{1}+0,550 X_{2} \\
& +0,136 X_{1} X_{3} \\
& -0,532 X_{2} X_{3}+e
\end{aligned}
$$

\section{Hasil Pengujian Pengaruh Partisipasi Penyusunan Anggaran terhadap Kinerja Manajerial}

Hasil analisis pada tabel di atas diperoleh pengaruh Partisipasi penyusunan anggaran yang signifikan terhadap Kinerja Manajerial. Hal ini dibuktikan dari nilai signifikansi $\mathrm{X}_{1}$ sebesar 0,002 (lebih kecil dari atau berada diantara nilai $0,000<0,05$. Hal ini menyatakan bahwa hipotesis pertama (H1) terdukung.

Hasil pengujian hipotesis pada penelitian ini menunjukan bahwa manajerial pemerintah pada OPD Provinsi Sulawesi Selatan berperan serta dalam penyusunan anggaran. Para pejabat struktural telah mendapatkan kompetensi melalui pendidikan dan pelatihan kedinasan sehingga mereka mampu memahami dengan baik tugastugasnya.

Hasil penelitian yang telah dilakukan oleh penelitian Wiratno, dkk (2016), Ridwan 
dan Putra (2016) dan Giusti (2018) yang menyatakan hal yang sama bahwa terdapat pengaruh signifikan antara partisipasi penganggaran terhadap kinerja manajerial.

\section{Hasil Pengujian Pengaruh Kejelasan Sasaran Anggaran terhadap Kinerja Manajerial}

Hasil analisis pada tabel di atas diperoleh pengaruh Kejelasan sasaran yang signifikan terhadap Kinerja Manajerial. Hal ini dibuktikan dari nilai signifikansi $\mathrm{X}_{2}$ sebesar 0,000 (lebih kecil dari atau berada diantara nilai $0,000<0,05$. Hal ini menyatakan bahwa hipotesis pertama (H2) terdukung.

Hasil pengujian hipotesis pada penelitian ini menunjukan bahwa pengukuran kinerja dalam Laporan Akuntabilitas Kineja Instansi Pemerintah (LAKIP) yang telah dibuat setiap akhir periode masing-masing OPD pada Provinsi Sulawesi Selatan tidak hanya berdasarkan aspek ekonomis, efektifitas dan efisiensi saja tetapi pengukurannya juga selalu memperhatikan belanja yang telah dikeluarkan apakah kejelasan sasaran anggarannya sudah jelas dan telah mencapai sasaran yang dicantumkan dalam Rencana Kerja Anggaran (RKA) yang nantinya akan dijadikan bahan dalam penyusunan anggaran OPD Provinsi Sulawesi Selatan.

Hasil penelitian ini mendukung hasil penelitian Beny (2012), Wahyuni.et.al (2014) dan Denny (2015) yang menunjukkan bahwa kejelasan sasaran anggran berpengrauh signifikan terhadap kinerja manajerial.

\section{Hasil Pengujian Pengaruh Partisipasi Penyusunan anggaran yang dimoderasi oleh locus of control terhadap Kinerja Manajerial}

Hasil rekapitulasi pada tabel di atas menunjukkan nilai signifikansi Moderat 1 sebesar 0,882 atau tidak berada diantara nilai $0,000<0,05$. Hal ini menyatakan bahwa hipotesis ketiha (H3) terdukung. Maka dapat disimpulkan bahwa variabel locus of control tidak mampu memoderasi hubungan partisipasi penyusunan anggaran terhadap kinerja manajerial pada Provinsi Sulawesi Selatan.

Hasil penelitian ini menunjukkan bahwa situasi kerja para Manajerial di OPD pada Provinsi Sulawesi Selatan tidak dalam situasi terdesak sehingga tidak menuntut seorang manajerial untuk memiliki karakteristik locus of control yang baik dalam partisipasinya menyusun anggaran.

Hasil penelitian ini mendukung hasil penelitian (Haryanto, 2018) menemukan bahwa locus of control tidak mampu memoderasi pengaruh partisipasi anggaran terhadap kinerja manajerial.

Hasil Pengujian Pengaruh Kejelasan Sasaran anggaran yang dimoderasi oleh locus of control terhadap Kinerja Manajerial

Hasil rekapitulasi pada tabel di atas diperoleh nilai nilai signifikansi Moderat 2 sebesar 0,505 atau tidak berada diantara nilai $0,000<0,05$. Hal ini menyatakan bahwa hipotesis keempat (H4) terdukung. Maka dapat disimpulkan bahwa variabel locus of control tidak mampu memoderasi hubungan kejelasan sasaran anggaran terhadap kinerja manajerial pada Provinsi Sulawesi Selatan.

Hasil penelitian ini menunjukan bahwa sasaran anggaran yang disusun secara jelas oleh para manajerial OPD Provinsi Sulawesi Selatan tidak ada kaitannya dengan locus of cotrol yang dimilikinya.

Hasil penelitian ini mendukung hasil penelitian (Threzasyari, 2017) menemukan bahwa locus of control memoderasi kejelasan anggaran terhadap senjangan anggaran.

\section{SIMPULAN DAN SARAN}

Hasil penelitian yang telah dilakukan maka dapat ditarik beberapa simpulan dari hasil analisis yaitu partisipasi penyusunan anggaran dan kejelasan sasaran anggaran berpengaruh positif dan signifikan terhadap kinerja manajerial. Locus of control tidak mampu memoderasi pengaruh partisipasi penyusunan anggaran dan kejelasan sasaran 
anggaran terhadap kinerja manajerial. Hasil penelitian ini dapat memberikan masukan kepada pemerintah Sulawesi Selatan yaitu masih diperlukan adanya kebijakankebijakan yang dapat meningkatkan locus of control bagi para Manajerial.

\section{DAFTAR PUSTAKA}

Bastian, I. (2010). Sistem Akuntansi Sektor Publik. Jakarta: Salemba Empat.

Beny Arifin, W. (2012). Pengaruh Partisipasi Anggaran, Kejelasan Sasaran Anggaran, Pengendalian Akuntansi Dan Sistem. Jurnal Akuntansi \& Investasi, 13(1), 1527.

Ferial, K. (2016, Februari). Pengaruh Partisipasi Penyusunan Anggaran dan Desentralisasi Terhadap Kinerja Manajerial Dengan Locus Of Control Sebagai Variabel Moderasi (Studi di Dinas Pekerjaan Umum Kabupaten Karanganyar). $e$ Jurnal UNISRI, XXVIII(No.2).

Giusti, G., Kustono, A. S., \& Effendi, R. (2018). Pengaruh Partisipasi Anggaran Terhadap Kinerja Manajerial dengan Komitmen Organisasi dan Motivasi Sebagai Variabel Intervening. e-Journal Ekonomi Bisnis dan Akuntansi, V(2), 121-128.

Haryanto. (2018). Pengaruh Partisipasi Anggaran Terhadap Kinerja Manajerial Dimoderasi Locus Of Control. FIPA(Forum Ilmiah Pendidikan Akuntansi, 6(2).

Threzasyari, Y. (2017). Pengaruh Partisipasi Anggaran dan Kejelasan Sasaran Anggaran Terhadap Senjangan Anggaran Dengan Locus Of Control Sebagai Variabel Moderasi. JOM Fekon, 4(1).

Rantelobo, A. T. (2018). Pengaruh Kinerja Manajerial Terhadap Partisipasi Penyusunan Anggaran dan Komitmen Organisasi pada Lima Satuan Kerja Perangkat Daerah Pemerintahan Kota Kupang. Jurnal Akuntansi,Keuangan dan Audit Vol. 3 No.1, 29-35.

Ridwan, M., \& Putra, W. E. (2016, Januari-Juni). Pengaruh Komitmen Organisasi, Gaya Kepemimpinan \& Struktur Organisasi
Terhadap Hubungan Antara Partisipasi Anggaran dengan Kinerja Manajerial (Studi Pada Rumah Sakit Swasta di Kota Jambi). ISSN:0852-8349, 18(1), 10-26.

Sugiyono. (2015). Metode Penelitian (Metode Kuantitatif, Kualitatif, $R \& D)$ ). Bandung: Alfabeta.

Threzasyari, Y. (2017). Pengaruh Partisipasi Anggaran dan Kejelasan Sasaran Anggaran Terhadap Senjangan Anggaran Dengan Locus of Control Sebagai Variabel Moderasi. JOM Fekon, 4(1).

Wiratno, A., Ningsih , W., \& Putri, N. K. (2016). Partisipasi Anggaran Terhadap Kinerja Manajerial dengan Komitmen Organisasi, Motivasi dan Struktur Desentralisasi sebagai Variabel Pemoderasi. Jurnal Akuntansi, $X X(01)$. 